\title{
«ИЛЛИРИЙСКИЙ МИФ» КАК ФАКТОР ФОРМИРОВАНИЯ НАЦИОНАЛЬНОЙ ИДЕНТИЧНОСТИ БАЛКАНСКИХ НАРОДОВ: ИСТОРИЯ И СОВРЕМЕННОСТЬ ${ }^{1}$
}

\begin{abstract}
Аннотация
В данной статье предпринимается попытка проследить корни формирования протохронистского политического мифа об «иллирийском происхождении» современных балканских народов. Показывается, как появилась идеология «иллиризма» и как выросший вокруг нее миф не ушел в прошлое, а продолжает быть значимым фактором современной политики на Балканах. Обращение к «иллирийскому мифу» является аргументом в многочисленных «войнах памяти» между молодыми балканскими государствами, помогая им выстраивать собственную политику памяти и национальной идентичности.
\end{abstract}

Ключевые слова: иллиризм, политика памяти, национальная идентичность, Балканы, политический миф.

DOI: 10.51180/RPS.2021.18.1.001

\section{Авторы}

\section{Болдин Владимир Алексеевич}

Кандидат политических наук, ассистент кафедры истории социально-политических учений факультета политологии МГУ имени М.В. Ломоносова (Москва, Россия)

\section{Страхов Александр Борисович}

Аспирант кафедры истории социально-политических учений факультета политологии МГУ имени М.В. Ломоносова (Москва, Россия)

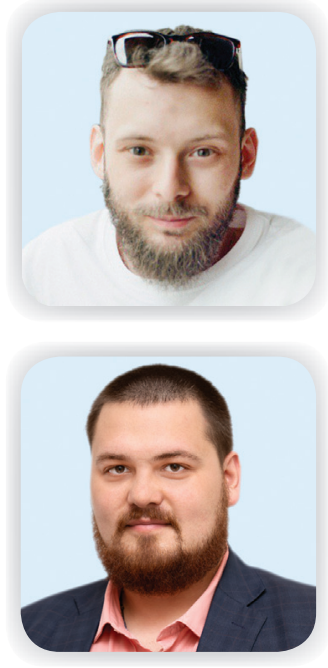

\footnotetext{
Овременный политический ландшафт Балканского полуострова получил свое оформление относительно недавно. Однако нельзя говорить о том, что сейчас он имеет законченный вид. Образовавшиеся на обломках Югославии новые молодые государства полны взаимных претензий друг к другу, как территориальных, так и в сфере "истории» и "памяти».

В поисках дополнительных аргументов в свою пользу историки и политики обращаются к концепциям прошлого, способным обеспечить дополнительную идеологическую почву для текущих политических притязаний. Одной из таких концепций стала идеология иллиризма, впервые появившаяся в XVI в., а затем нашедшая отражение в работах идеологов хорватского Возрождения

1 Исследование выполнено за счет гранта Президента Российской Федерации для государственной поддержки молодых российских ученых - кандидатов наук (проект МК-1526.2020.6 «Славянская идея: от национального самоопределения к европейской интеграции (историко-политологический анализ)»).
} 
XIX в. Иллиризм заявлял о единстве всех славянских народов, населяющих Балканский полуостров, а их предками объявлял древних иллирийцев, населявших эти территории в античные времена. Удивительным образом «миф об иллирийском происхождении» оказался удивительно живучим ${ }^{1}$. Он стал одним из тех, которые современные исследователи характеризуют как «протохронистический миф» [22]. Его цель - утвердить представление о древности нации, обосновать ее право на определенные территории или место на мировой политической арене, апеллируя к образам великого, но некогда утраченного прошлого [9. С. 44]. Не исключение и «иллирийский миф", который стал активно использоваться для "удревления" истории молодых балканских наций, обоснования их автохтонности и, следовательно, территориальных претензий. Причем «иллирийский миф» не только является частью политического дискурса славянских народов Балкан, но и активно используется албанскими политиками, например, для обоснования косовской государственности [7. - С. 69-70].

\section{Иллиризм как интегративная наднациональная идеология}

Появление первых концепций иллиризма обычно возводят к XVI в., когда хорватский гуманист родом из Далмации Винко Прибоевич «Выдвинул идею о единых корнях обитавших на западе Балкан славянских народов и их происхождении от древнего народа иллирийцев» [7. - С. 67]. Именно Далмацию принято считать родиной иллиризма. Во многом это происходит из-за того, что в XVI в. Далмация представляла собой фронтирный регион, где пересекались интересы Турецкой империи и Венецианской республики. В попытке сохранить собственную

\footnotetext{
1 Подробнее о роли мифов в политике см.:
} [20; 21. - C. 115-130]. национальную и культурную идентичность далматинскими священнослужителями и была сформулирована идея иллиризма, говорящая о родстве славянских народов. Данное обстоятельство является показательным. Ведь часто рождение панидеологий, к каковым можно отнести и иллиризм, становилось идеологическим ответом на те кризисные ситуации, которые раскалывали общество. Идеологи пандвижений видели своей задачей поиск путей преодоления сложившихся ситуаций, выработку новых направлений развития и модернизации общества, культурной интеграции и мобилизации. А главным шагом на этом пути должно было быть создание единого государства (союза) с родственными в культурно-языковом плане народами [2. С. 41]. В дальнейшем идеи иллиризма в разной степени нашли продолжение в произведениях гуманиста Юрая Шижгорича, поэта Илии Цриевича, историка Мавро Орбини, философа и богослова Юрия Крижанича и многих других славянских деятелей той эпохи [7. С. $67 ; 3 .-$ C. 182-191; 4. - С. 55-69]. Примечательно, что «Иллирия Крижанича распространялась от Черного до Адриатического моря, охватывая всех балканских славян, от болгар и сербов до хорватов и словенцов» [1. - С. 344].

Следующий всплеск интереса к идеям иллиризма происходит после наполеоновских войн, когда в Австрийской империи назрел австро-венгерский конфликт, в котором активное участие приняло и хорватское общественное движение. Имперские власти, вынужденные делать уступки то венграм, то хорватам, старались найти в последних противовес венгерскому национальному движению, представлявшему серьезную опасность дому Габсбургов. На этом фоне возник национальный подъем хорватского народа. Основными идеологами национального Возрождения хорватских земель стали хорватский поэт Людевит Гай, хорватский общественный деятель, писатель 
Иван Кукулевич-Сакцинский, хорватский политик граф Янко Драшкович, словенский поэт Станко Враз, которые исходили из факта этнического родства всех южных славян и идеала их национального единства. Считая, что южные славяне являются потомками древних иллирийцев, деятели хорватского Возрождения называли их иллирийским народом. В связи с этим хорватское национальное Возрождение получило название иллирийского движения, иллиризма 1 .

Важным пунктом программы иллирийского движения было культурное и духовное единение всех южных славян. Именно для этой цели предполагалось создание единого литературного языка как основы объединения будущей нации. Для сплочения нации «иллиры» приняли в качестве литературного языка не кайкавский диалект Хорватии, а наиболее развитый и распространенный штокавский диалект (на штокавшину Гай перевел свои издания) ${ }^{2}$, так как на нем говорили все сербы и боснийские мусульмане, что позволяло преодолеть языковой рубеж между народами [16. - С. 5].

Взгляды на объединение южнославянских племен у представителей иллиризма были не столь однозначны, как может показаться. Основными противоречиями во взглядах «иллиров» стали восприятие политики сербского правительства, в частности, его национально-политической программы - «Начертание» Илии Гарашанина [6. - С. 235-249], как угрозы хорватским территориям, сотрудничество с властями Австрийской империи, которые использовали зарождающиеся

1 Подробнее об исторических предпосылках появления иллиризма: [14].

${ }^{2}$ Как пишет переводчик программной статьи Л. Гая «Наш народ" А.В. Мырикова, выбор штокавского диалекта был обусловлен тем, что «Гай убедился, что кайкавское наречие, во-первых, не имеет литературной традиции, а во-вторых, мало понятно другим ветвям сербохорватской народности» [3. - С. 87]. национальное движение в Хорватии как орудие в борьбе против венгерского сепаратизма ${ }^{3}$, наличие во взглядах некоторых идеологов иллиризма элементов католического экспансионизма, что, естественно, вызывало отпор у сербской и боснийской части южнославянского племени, для которых национальная религия являлась фундаментальной и неотъемлемой частью собственного культурного и национального самосознания.

Что касается политической программы иллирийского движения, то наиболее четко ее можно проследить на основе требований, которые иллирийские группировки выдвигали в марте 1848 г., в период политического кризиса внутри Австрийской империи. Ключевыми требованиями были: объединение хорватских земель, создание национального правительства, ответственного перед Сабором ${ }^{4}$, демократические свободы, ликвидация сословных привилегий и феодальной зависимости крестьян ${ }^{5}$. Более того, лидеры иллиризма поддержали назначение на пост бана ${ }^{6}$ полковника Йосипа Елачича, верного императору и вместе с тем близкого национальному

3 Так, например, русский ученый и общественный деятель А.Ф. Гильфердинг характеризовал л. Гая, виднейшего деятеля иллиризма, как «одно из самых искусных орудий австрийской политики». Русский филолог-славист, один из основателей отечественной школы славяноведения, И.И. Срезневский и вовсе обвинял Л. Гая в «антиславизме» и чрезмерном угождении «венской политике» [8. - С. 286-287]. Также об этом см.: [19. - С. 87].

${ }^{4}$ Сабор - представительный орган, созданный в Хорватии в годы революции 18481849 гг. - В. Б., А. С.

5 В марте 1848 года в Загребе состоялось собрание деятелей национального движения («Великая народная скупщина»), в ходе которого и был сформулирован программный документ «Требования народа». Подробнее полный текст документа см.: [19. - С. 139-141].

${ }^{6}$ Бан - военно-политический титул, принятый у южных славян и означавший правителя области. В данном контексте титул «бана» обозначает наместника императора Австрийской империи в Хорватии. - B. Б., A. C. 
движению. Это олицетворяло их линию на компромисс с Веной. Таким образом, иллиры выступили за преобразование Австрийской империи на конституционных и федералистских началах.

Иллиризм добился определенных политических завоеваний (отделение Хорватии от земель венгерской короны, учреждение в Загребе независимого архиепископства, введение преподавания в школах на национальном языке) в ходе революционных событий 1848 г., во многом благодаря поддержке Австрии в конфликте с Венгрией. Но эти достижения оказались недолговечными, и уже к 1850 г. иллиризм потерял былые позиции ${ }^{1}$. Тем не менее обращение идеологов иллиризма к античному прошлому преследовало целью доказать автохтонность балканских народов и их не менее древнюю культуру по сравнению с немцами и венграми. Как пишет современный исследователь М.Ю. Ломоносов, «древность и богатство исторического прошлого, способность к историческому развитию, большая роль в продвижении европейской культуры утверждали справедливость национальной борьбы южных славян за равноправие и свободу, неизбежность их победы» [9. - С. 48].

В дальнейшем некоторые взгляды сторонников иллиризма нашли продолжение в идеологии «югославизма», ратовавшей за объединение всех южных славян в единое государство на демократических началах [5. - С. 8082]. Однако на Балканском полуострове значительную популярность приобрели и националистические «панидеологии» - «Великой Сербии» и «Великой Хорватии», создатели которых видели путь интеграции южных славян лишь под властью одного из народов - сербов или хорватов, полностью отрицая национальную и культурную самобыт-

1 К 1851 году был распущен хорватский Са6ор, постепенно происходил процесс централизации власти и, как следствие, сокращение автономии Хорватии [14. - С. 22]. ность других этносов $[15 ; 13 .-$ С. 18-24; 15. - C. 3-10; 17. - C. 201-230].

\section{Реинкарнация «иллирийского мифа" в современном политическом дискурсе}

Удивительным образом «иллирийский миф» стал снова актуален во второй половине XX в. К его реинкарнации были причастны боснийские и албанские историки, которые в поисках путей для обоснования собственных концепций национальной истории и национальной памяти прибегли к тому, что в современной науке получило название «мобилизация средневековья" [12. - С. 22-39]. С начала 60-х гг. XX в. боснийскими учеными стала активно разрабатываться идея о «романских корнях» автохтонных народов Балкан, к каковым относились, по их мнению, в том числе и бошняки с албанцами. Выдающийся югославский историк Ф. Папазоглу сформулировала концепцию, согласно которой на территории современных Балкан существовало единое иллирийское государство, население которого приходилось прямыми предками современным югославским народам [23. - С. 143-179]. Сами по себе эти концепции и представления находились в плоскости исторической науки, однако уже в 90-х гг. ХХ в. активно интегрировались в политику, а идеи о «древности» и «автохтонности» албанской и боснийской нации стали активно использоваться элитами этих стран для обоснования собственных территориальных и политических притязаний. Как пишет А.В. Колобов, «в 1990-х гг. после распада союзной республики Югославии иллиризм в его дарданском варианте стал идеологическим обоснованием борьбы наиболее радикально настроенных политических сил албанцев Косово и Македонии за выход из состава славянских государств и создание собственной политической структуры» [7. - С.67]. Интересно, что «иллирийский миф» был так же вос- 
принят ичерногорской элитой, которая примерно в это же время заговорила об обособленности черногорцев от сербов [11. - С. 189-401].

Отражение «иллирийского мифа» в политическом дискурсе балканских политиков требует отдельного исследования. Приведем лишь один показательный пример использования этого «мифа» в политических целях. В 1994 г. тогда президент непризнанной республики Косово Ибрагим Ругова в одном из интервью заявил, что косовские албанцы являются предками древних иллиров, и, следовательно, были здесь всегда, а не являются «пришлыми» на Балканы, как славянские народы. Кроме того, косовские албанцы имели в прошлом и свою государственность королевство Дардания, известное европейским средневековым историкам [24. - F. 154]. Именно албанцы объяв- лялись хранителями древней культуры, разрушенной с приходом сербов.

Таким образом, можно утверждать, что «протохронистический» по своей природе миф об «иллирийском прошлом» постоянно актуализируется в политическом дискурсе балканских народов на протяжении истории. В разные годы его носители преследовали разные цели: от сохранения национальной культуры и интеграции до построения собственных независимых «наций-государств» и обособления от других балканских народов. Все это говорит о большом внутреннем потенциале этого «мифа», а значит, аргументы в пользу «иллиризма» будут использоваться в "войнах памяти" и «войнах за историю", которые еще долго будут греметь на полях академических конференций и с высоких политических трибун.

\section{Литература}

1. Бадалич И.М. Юрий Крижанич - поэт Иллирии // Труды Отдела древнерусской литературы. - 1958. - Т. 14. - С. 341-348.

2. Болдин В.А. Панславистские политические концепции: генезис и эволюция / Под общ. ред. А.А. Ширинянца. - М., 2018.

3. Болдин В.А., Страхов А.Б. Национальное vs общеславянское в русских источниках XVII века // Диалог со временем. — 2020. — № 71. - C. 182-191. — DOI: 10.21267/ AQUILO.2020.71.63626.

4. Дронов А.М. От иллиризма к хорватизму в Австрийской империи первой половины XIX века // Славяноведение. - 2018. - № 1. - С. 55-69.

5. Ефременко Д.В., Мелешкина Е.Ю. Югославский метанарратив и современная югоностальгия в странах Западных Балкан // Политическая экспертиза: ПОЛИТЭКС, 2020. T. 16. — № 1. - C. 79-100. — DOI: 10.21638/spbu23.2020.105.

6. Илия Гарашанин. «Начертание» // Никифоров К.В. «Начертание» Илии Гарашанина и внешняя политика Сербии в 1842-1853 гг. - М., 2015. - С. 235-249.

7. Колобов А.В. Иллиризм как фактор политической истории балканского региона в XIX-XX вв. // Вестник Пермского университета. Серия «История». - 2004. - Вып. 5. С. $67-72$.

8. Кулаковский П. Иллиризм. Исследование по истории хорватской литературы периода Возрождения. - Варшава, 1894.

9. Ломоносов М.Ю. Иллирийский миф в интерпретации славянских интеллектуалов Западных Балкан (XV-XXI вв.) // Вестник славянских культур. - 2011. — № 4. - С. 44-55.

10. Мырикова А.В. Статья Людевита Гая «Наш народ» //SCHOLA-2013. Материалы Международной научной конференции «Политика в текстах — тексты в политике: наука истории идей и учений», 30-31 октября 2013 года. - М., 2013. - С. 153-157.

11. Никифоров К.В. Сербская государственность в начале XXI в. // Двести лет новой сербской государственности. - СПб., 2005. - С. 388-402.

12. Филюшкин А.И. Мобилизация Средневековья» как инструмент формирования представлений о славянском единстве // Studia Slavica et Balcanica Petropolitana. - 2017. № 2. - C. 22-39. - DOI: 10.21638/11701/spbu19.2017.202. 
13. Фрейдзон В.И. Хорватский национальный радикализм (Великохорватская идеология) в 19 веке // Славяноведение. - 1998. — № 5. - С. 18-24.

14. Фрейдзон В.И. Борьба хорватского народа за национальную свободу. - М., 1970.

15. Фрейдзон В.И. История Хорватии. Краткий очерк с древнейших времен до образования республики (1991 г.). - СПб., 2001.

16. Фрейдзон В.И. Хорватский Югославизм в 30-90-е годы XIX века // Славяноведение. 1998. - № 5. - С. 3-10.

17. Фрейдзон В.И. Югославизм и «великие идеи» у хорватов и сербов монархии Габсбургов во второй половине 19 века // На путях к Югославии: за и против. - М., 1997. C. 201-230.

18. Хобсбаум Э. Нации и национализм после 1780 г. - СПб., 2017.

19. «Требования народа» // Симакова О.А. История южных славян с древнейших времен до 1914 г.: Уче6.-метод. комплекс для студ. ист. фак.. - Минск, 2007. - С. 139-141.

20. Ширинянц А.А., Васич В.Н. Политика. Культура. Время. Мифы. - М., 1999.

21. Ширинянц А.А. Русь, куда ж несешься ты? Мифы в культуре и политике // Środkowoeuropejskie Studia Polityczne. — 2019. — № 4. - C. 115-130. —DOI: 10.14746/ssp.2019.4.6.

22. Boia L. History and myth in Romanian consciousness. - Budapest, 2001.

23. Papazoglu F. Les origines et la destinee de l'etat illyreen: illyrii proprie dicti // Historia. 1965. - № 15. - P. 143-179.

24. Rugova I. Çështja e Kosovës. - Prishtinë, 2005. 